BBA 65073

\title{
PURIFICATION AND SOME PROPERTIES OF $\beta$-GALACTOSIDASE OF BACILLUS SUBTILIS
}

\author{
P. J. ANEMA \\ Botanical Laboratory, The State University of Utrecht, \\ Utrecht (The Netherlands)
}

(Received March 25th, I964)

\begin{abstract}
SUMMARY
I. $\beta$-Galactosidase ( $\beta$-D-galactoside galactohydrolase, EC 3.2.I.23) was isolated from Bacillus subtilis and partially purified.

2. When the measurements were made at saturating or nearly saturating concentrations of substrate there was a linear relationship between the quantity of enzyme and the amount of product formed, and a linear formation of product with time. The enzymic activity was not influenced by ions.

3. The optimum $\mathrm{pH}$ for hydrolytic activity was 6.5 .

4. The optimum temperature for hydrolysis was $50^{\circ}$. The enzyme was relatively heat-stable. The enzyme was not inactivated during $\mathrm{I} \mathrm{h}$ at $50^{\circ}$. At $55^{\circ}$ the inactivation was $15 \%$ after 30 min of exposure.

5. The affinity constant for lactose was $7 . I \cdot 10^{-1}$. The constants for the common substrates of the $\beta$-galactosidase of $B$. subtilis were different from those of the Escherichia coli enzyme.
\end{abstract}

\section{INTRODUCTION}

The hydrolytic enzyme $\beta$-galactosidase ( $\beta$-D-galactoside galactohydrolase, EC 3.2.I.23) of Escherichia coli has been extensively investigated. Several authors have described its purification ${ }^{1-3}$ and crystallization ${ }^{4,5}$. The genetic control of the regulation of the biosynthesis of the enzyme in this organism has been analysed by recombination ${ }^{6-8}$ and transduction ${ }^{9-11}$ experiments. LANDMAN ${ }^{12}$ studied some properties and the induction of the enzyme in Bacillus megatherium. CLAUSEN AND NAKAMURA ${ }^{13}$ investigated the enzyme of Shigella sonnei. So far, no attention has been paid to the $\beta$ galactosidase of Bacillus subtilis, although the organism can be genetically analysed by transformation ${ }^{\mathbf{1 4}, 15}$ and transduction ${ }^{16}$ experiments. In this paper a procedure for the purification of the $\beta$-galactosidase of $B$. subtilis is presented, and some of its properties are described.

Abbreviations: ONPG, o-nitrophenyl- $\beta$-D-galactoside; ONP, 0 -nitrophenol; IPTG, isopropyl- $\beta$-D-thiogalactoside. 
Organism and medium

The strain used was a constitutive mutant isolated from the Marburg strain by the method of COHEN-BAzIRE AND JoLIT ${ }^{17}$. Wild-type cells were grown alternately $8 \mathrm{~h}$ in synthetic medium containing $0.5 \%$ glucose and $\mathrm{r} 6 \mathrm{~h}$ in synthetic medium containing $0.5 \%$ lactose. After one month a constitutive mutant was isolated which had a 25 -fold $\beta$-galactosidase production in comparison with the wild type grown in a medium supplemented with lactose.

The cells were grown at $37^{\circ}$ on reciprocal shakers in the following medium (g/l): $\left(\mathrm{NH}_{4}\right)_{2} \mathrm{SO}_{4}, 2 ; \mathrm{KH}_{2} \mathrm{PO}_{4}, 6 ; \mathrm{K}_{2} \mathrm{HPO}_{4}, \mathrm{I}_{4} ; \mathrm{MgSO}_{4} \cdot 7 \mathrm{H}_{2} \mathrm{O}, 0.2 ; \mathrm{FeCl}_{3} \cdot 6 \mathrm{H}_{2} \mathrm{O}, 0.0 \mathrm{I}$; $\mathrm{MnSO}_{4} \cdot 4 \mathrm{H}_{2} \mathrm{O}$, 0.00025; peptone, 0.2 ; lactose $\cdot \mathrm{H}_{2} \mathrm{O}, 5$. The $\mathrm{pH}$ of the medium was 7.0 .

\section{Enzyme assay}

Enzymic activity was assayed with a modification of the method of REVEL, LURIA AND Rotman ${ }^{9}$. A mixture of $0.0 \mathrm{Iml}$ of enzyme (max. 600 units); I ml o.I M sodium-potassium phosphate buffer $(\mathrm{pH} \mathrm{6.5)}$ and $0.6 \mathrm{ml}$ of distilled water were brought to $50^{\circ}$. Then I $\mathrm{ml}$ prewarmed $0.25 \mathrm{M}$ sodium-potassium phosphate buffer ( $\mathrm{pH}$ 6.5) containing $\mathrm{I} 4 \mathrm{mg}$ ONPG was added. After $5 \mathrm{~min}$ incubation at $50^{\circ}$ the reaction was stopped by addition of $1.3 \mathrm{ml} \mathrm{I} \mathrm{M}$ sodium carbonate. The absorbancy of the chromogen was measured at $420 \mathrm{~m} \mu$ in a Zeiss spectrophotometer. One unit of enzyme is defined as the amount that releases I m $\mu$ mole of ONP per min at $50^{\circ}$ and $\mathrm{pH}$ 6.5. A solution of $\mathrm{I} \mathrm{m} \mu$ mole of ONP per $\mathrm{ml}$ has an absorbancy of 0.005 under the above conditions (final $\mathrm{pH}$ ro.2; ro $\mathrm{mm}$ light path).

\section{Protein determination}

Protein was determined spectrophotometrically by measuring the absorption at 280 and $260 \mathrm{~m} \mu$ (ref. I8).

\section{Reagents}

ONPG was obtained from Sigma Chemical Company, IPTG from Mann Research Laboratories and Streptomycin sulphate from Mycofarm, Delft.

\section{EXPERIMENTS AND RESULTS}

The cells were centrifuged at the end of the logarithmic phase, washed once with saline and a second time with o.or $\mathrm{M}$ phosphate buffer $(\mathrm{pH}$ 7.0). The bacteria were then packed at $27000 \times g$ in a Servall RC-2 centrifuge. The wet cells (IOo g) were resuspended in $200 \mathrm{ml}$ o.or $\mathrm{M}$ phosphate buffer $(\mathrm{pH} \mathrm{7.0)}$ and ruptured in batches of $24 \mathrm{ml}$ with $\mathrm{I} 6 \mathrm{~g}$ ballotini beads No. I5 (English Glass Company, Leicester) in the Cell homogenizer of MERKENSCHLAGER ${ }^{19}$ at $2500 \mathrm{rev} . / \mathrm{min}$ during $3 \mathrm{~min}$. The cell debris was spun down at $27000 \times g$ during $30 \mathrm{~min}$. The brownish red crude extract could be stored for at least 3 weeks at $-20^{\circ}$ without loss of activity. 


\section{Purification}

Step. I Nucleic acid precipitation. To the extract $(\mathrm{I} 20 \mathrm{ml}) 7 \mathrm{ml}$ of a $50 \%$ streptomycin sulphate solution in $0.01 \mathrm{M}$ phosphate buffer $(\mathrm{pH} 7.0)$ were slowly added with stirring at $4^{\circ}$. The mixture was allowed to stand in ice for $20 \mathrm{~min}$ and centrifuged in the cold for $30 \mathrm{~min}$ at $27000 \times \mathrm{g}$. The clear yellow supernatant was retained for protein precipitation, and the nucleic acid containing residue was discarded ${ }^{4}$.

Step 2. First ammonium sulphate fractionation. The solution was brought to $45 \%$ saturation with $\left(\mathrm{NH}_{4}\right)_{2} \mathrm{SO}_{4}$ by slow addition with stirring of a saturated salt solution ( $\mathrm{pH} 7.2$ ), kept in the cold for $25 \mathrm{~min}$, and centrifuged at $4^{\circ}$ for $30 \mathrm{~min}$ at $27000 \times \mathrm{g}$. The supernatant was brought to $65 \%$ saturation with the $\left(\mathrm{NH}_{4}\right)_{2} \mathrm{SO}_{4}$ solution. After $25 \mathrm{~min}$ the mixture was centrifuged and the precipitate was dissolved in $32 \mathrm{ml} \mathrm{o.or} \mathrm{M}$ sodium-potassium phosphate buffer ( $\mathrm{pH} 7.0$ ).

The fractionations were performed in rapid succession because inactivation of the enzyme in the $\left(\mathrm{NH}_{4}\right)_{2} \mathrm{SO}_{4}$ solutions was observed.

Step 3. Acetone precipitation. Prechilled acetone $(\mathrm{r} 6 \mathrm{ml})$ was added slowly with stirring to $32 \mathrm{ml}$ of the enzyme solution of Step 2. The mixture was allowed to stand for $\mathrm{I} 5 \mathrm{~min}$ in a $-10^{\circ}$ bath and centrifuged at $-10^{\circ}$ at $27000 \times \mathrm{g}$ for $25 \mathrm{~min}$. To the supernatant $8 \mathrm{ml}$ of acetone were added. After $15 \mathrm{~min}$ at $-10^{\circ}$ the suspension was centrifuged as before. The supernatant was discarded and the precipitate dissolved in to $\mathrm{ml}$ of phosphate buffer $(\mathrm{pH} 7.0)$. This fraction was dialysed with stirring against $500 \mathrm{ml}$ of the same buffer at $4^{\circ}$ for $23 \mathrm{~h}$.

TABLE I

\begin{tabular}{|c|c|c|c|c|c|c|}
\hline Step & $\begin{array}{c}\text { Total } \\
\text { volume } \\
(\mathrm{ml})\end{array}$ & $\begin{array}{l}\text { Total } \\
\text { units } \\
\times \mathrm{IO}^{-\mathbf{3}}\end{array}$ & $\begin{array}{c}\text { Total } \\
\text { protein } \\
\text { (mg) }\end{array}$ & $\begin{array}{l}\text { Units/mg } \\
\text { protein } \\
\times 10^{-3}\end{array}$ & $\begin{array}{c}\text { Yield } \\
(\%)\end{array}$ & $\begin{array}{c}\text { Overall } \\
\text { purifi- } \\
\text { cation }\end{array}$ \\
\hline Crude extract & 120 & 4262 & 360 & I 2 & Ioo & - \\
\hline Nucleic acid precipitate & 127 & 4262 & 360 & 12 & IOO & 一 \\
\hline First $\left(\mathrm{NH}_{4}\right)_{2} \mathrm{SO}_{4}$ fractionation & 33 & 4208 & I 2 I & 35 & 98 & 2.9 \\
\hline Acetone precipitate & 10 & 2240 & I 8 & 119 & 52 & IO.I \\
\hline Second $\left(\mathrm{NH}_{4}\right)_{2} \mathrm{SO}_{4}$ fractionation & 4 & I434 & 6 & 239 & 33 & 20.3 \\
\hline
\end{tabular}

Step 4. Second ammonium sulphate fractionation. The dialysed solution was brought to $45 \%$ saturation by addition of saturated $\left(\mathrm{NH}_{4}\right)_{2} \mathrm{SO}_{4}(\mathrm{pH} 7.2)$, kept in an ice bath for $25 \mathrm{~min}$ and centrifuged at $4^{\circ}$ for $25 \mathrm{~min}$ at $27000 \times \mathrm{g}$. The supernatant was brought to $55 \%$ saturation, allowed to stand for $25 \mathrm{~min}$ and centrifuged. The precipitate was dissolved in $4 \mathrm{ml}$ o.or $\mathrm{M}$ phosphate buffer $(\mathrm{pH} 7.0$ ), and dialysed for $25 \mathrm{~h}$ against three batches of $750 \mathrm{ml}$ of the same buffer. Table I summarizes the recovery and purification for each step. A 20-fold overall purification was achieved with about $33 \%$ recovery of enzyme activity. The purified extract could be stored below $-20^{\circ}$ for at least 3 months without loss of activity. Further attempts at purification by means of absolute methanol were unsuccessful, because this alcohol rapidly inactivated the enzyme. 


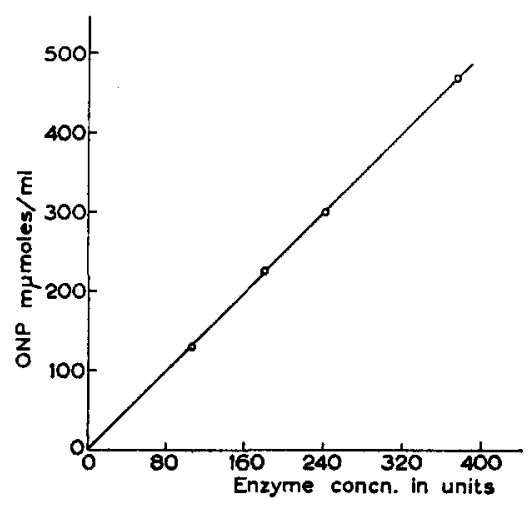

Fig. r. Relationship between enzyme concentration and rate of hydrolysis. Various concentrations of enzyme were tested under optimal conditions in the standard assay as described under Materials and Methods.

\section{Some properties of the enzyme}

Enzyme concentration and time course. Under optimal conditions, there was a linear relationship between the rate of hydrolysis and the concentration of the enzyme (Fig. I).

When ONPG was hydrolysed by the enzyme during various incubation times at $50^{\circ}$ and optimal $\mathrm{pH}$, the amount of product formed was linear with time during the first $\mathrm{I}_{5} \mathrm{~min}$ (Fig. 2).

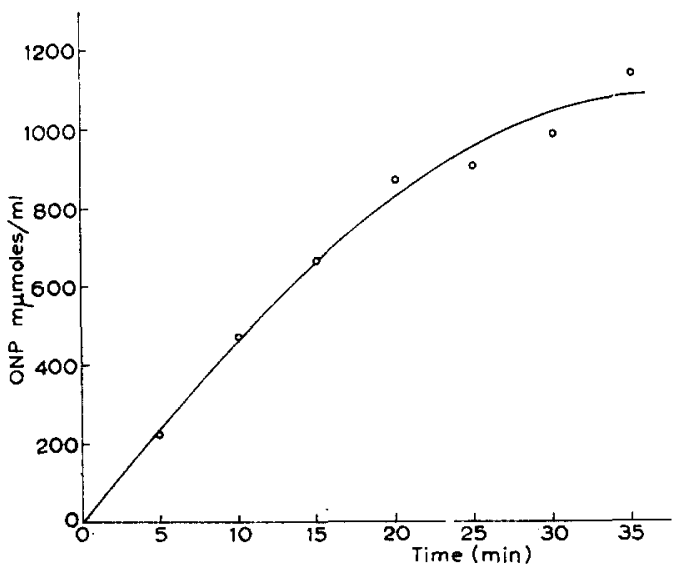

Fig. 2. Rate of hydrolysis of ONPG during incubation under optimal conditions.

Activity at various $p H$ values. The activity of the enzyme was measured in sodium-potassium phosphate buffers of various $\mathrm{pH}$ values. The maximal activity of the enzyme was at pH 6.5 (Fig. 3). 


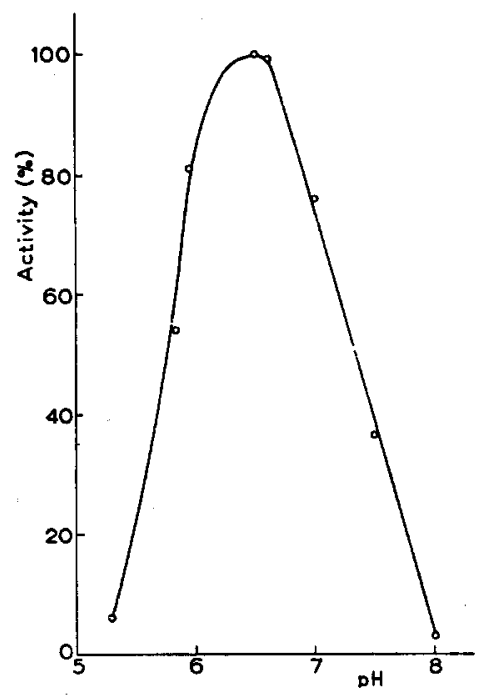

Fig. 3. Effect of $\mathrm{pH}$ on enzyme activity. The phosphate buffer ( $\mathrm{pH}$ 6.5) of the standard reaction mixture was substituted by phosphate buffers of various $\mathrm{pH}$ values.

Ion effects. Variation of the concentration of the sodium-potassium phosphate buffer had no influence on enzyme activity. Whether sodium phosphate or potassium phosphate buffer were used, the activity was unaffected. No influence of the following cations and anions could be detected in the standard reaction mixture: $\mathrm{NH}_{4}^{+}, \mathrm{Ba}^{2+}$, $\mathrm{Ca}^{2+}, \mathrm{Li}^{+}, \mathrm{Fe}^{3+}, \mathrm{Mn}^{2+}, \mathrm{Mg}^{2+} ; \mathrm{Cl}^{-}, \mathrm{SO}_{4}^{2-}, \mathrm{CO}_{3}^{2-}, \mathrm{NO}_{3}{ }^{-}$.

Temperature optimum and thermal inactivation. No $\beta$-galactosidase activity was detected in preliminary experiments in cells grown with lactose as carbon and energy source. In early experiments the enzyme activity was routinely measured at $28^{\circ}$. In later experiments it was found that the activity of the enzyme at this

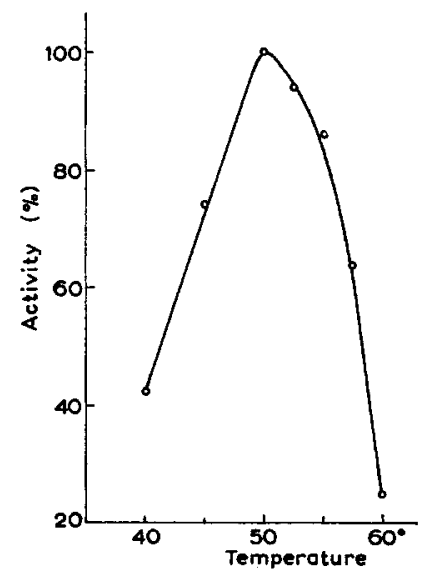

Fig. 4. Effect of temperature on enzyme activity. Standard reaction mixtures were incubated at various temperatures during $5 \mathrm{~min}$. 
temperature was very low. The optimal temperature of the enzyme was determined

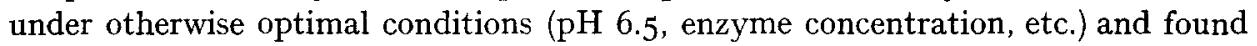
to be $50^{\circ}$ (Fig. 4).

An exposure to $50^{\circ}$ caused no loss of activity of the enzyme even after $90 \mathrm{~min}$. At $55^{\circ}$ the inactivation was $15 \%$ after 30 min of exposure, whereas at $60^{\circ}$ the inactivation was $50 \%$ after 2 min.

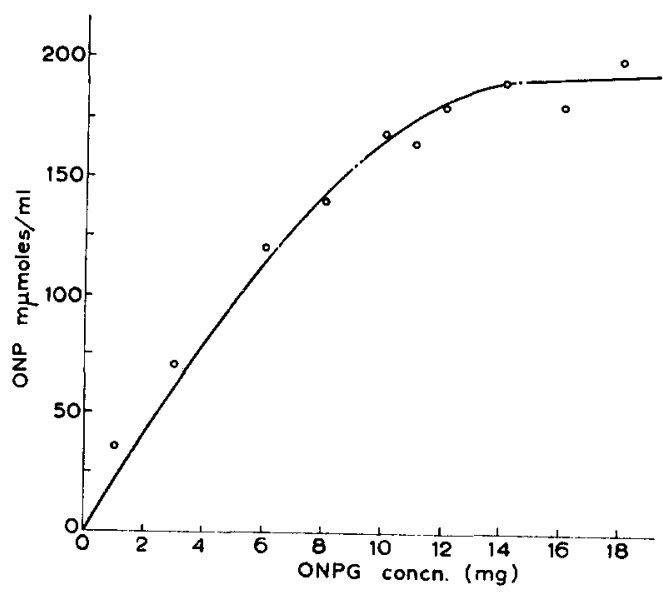

Fig. 5. Effect of ONPG concentration in the standard assay.

Affinity relations. The influence of $O N P G$ concentration on the rate of hydrolysis is shown in Fig. 5. The amount of enzyme used in most of the experiments (I60 units) was saturated with $\mathrm{I}_{4} \mathrm{mg}$ ONPG in the reaction mixture.

The affinities of lactose, galactose and IPTG for the enzyme were measured in a series of tests, in which the inhibition of ONPG hydrolysis by a fixed concentration of inhibitor was estimated at various $O N P G$ concentrations. The results, plotted by the LINEwEAVER-BURK method ${ }^{20}$ (Fig. 6), gave the $K$ values shown in Table II.

\section{TABLE II}

A COMPARISON OF SOME PROPERTIES OF THE $\beta$-GALACTOSIDASES OF $B$. subtilis, E. coli AND B. megatherium

\begin{tabular}{lccc}
\hline & B. subtilis & E. coli & B. megatherium \\
\hline pH optimum & 6.5 & 7.0 & - \\
Inactivation at $55^{\circ}$ after & & & \\
$\quad 5$ min & $0 \%$ & $100 \%$ & $42 \%$ \\
$K_{\mathrm{m}}$ (ONPG) & $4.2 \cdot 10^{-2}$ & $\mathrm{I} .8 \cdot 10^{-4}$ & $1.6 \cdot 10^{-4}$ \\
$K_{1}$ (lactose) & $7.1 \cdot 10^{-1}$ & $\mathrm{I} . \mathrm{I} \cdot 10^{-8}$ & $1.8 \cdot 10^{-3}$ \\
$K_{1}$ (galactose) & $4.2 \cdot 10^{-2}$ & $\mathrm{I} . \mathrm{I} \cdot 10^{-3}$ & $1.6 \cdot 10^{-2}$ \\
$K_{\mathrm{I}}$ (IPTG) & $1.2 \cdot 10^{-1}$ & $2.6 \cdot 10^{-4}$ & $3.2 \cdot 10^{-4}$ \\
\hline
\end{tabular}

$K_{\mathrm{m}}$ or $K_{1}$ in moles/l. 


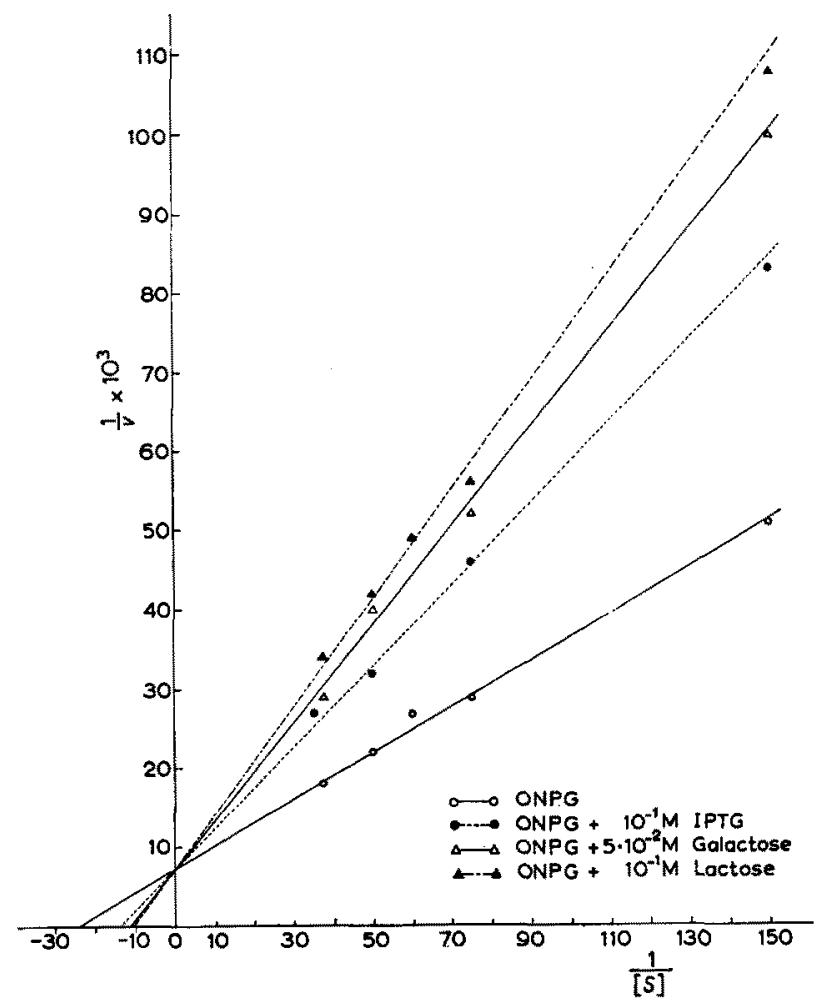

Fig. 6. LINEwAEVER-BURk plot for the determination of the Michaelis constant for ONPG and the inhibitor constants for lactose, galactose and IPTG.

\section{DISCUSSION}

There was a linear relationship between the quantity of enzyme and the amount of product formed, and a linear formation of product with time, when the measurements were made at saturating or nearly saturating concentrations of substrate, or when measurements were made at points where only a small fraction of the substrate had been converted. Similar results have been found with the $\beta$-galactosidase from $E$. coli ${ }^{1}$.

The pH optimum of the $B$. subtilis enzyme was close to 6.5 , whereas the optimum of the enzyme of $E$. coli $i^{1,2,5}$ is about 7.0. The results of LANDMAN ${ }^{12}$ with $B$. megatherium are not comparable with our results because he used the continuous method to measure ONPG hydrolysis. In this way it is only possible to measure the optimum $\mathrm{pH}$ of the coloured tautomer of ONP, and it is not possible to measure the optimum $\mathrm{pH}$ for enzyme activity.

Ions have a stimulating or inhibiting effect on the activity of the $\beta$-galactosidase of $E$. coli $1,2,21$ but they had no influence on the activity of the enzyme of $B$. subtilis.

The stability of the three enzymes at high temperature is completely different. The $B$. subtilis enzyme was not inactivated at $50^{\circ}$. It was $15 \%$ inactivated during 
an exposure of $30 \mathrm{~min}$ to $55^{\circ}$; and it was totally inactivated in a few minutes at $60^{\circ}$. The enzyme of $E$. coli is rapidly inactivated above $40^{\circ}$ (ref. 5 ). At $50^{\circ}$ about $94 \%$ of the enzyme is inactivated after $9 \mathrm{~min}$ of exposure, and at $55^{\circ}$ the enzyme is totally inactivated in I min (ref. 2). On the contrary JANECEK AND RICKENBERG ${ }^{22}$ found no inactivation at $50^{\circ}$ with a $\beta$-galactosidase extract from $E$. coli ML 30 after I 2 min of exposure. A 5-min exposure of the $\beta$-galactosidase from $B$. megatherium in $0.5 \mathrm{M}$ $\mathrm{K}_{2} \mathrm{HPO}_{4}$ resulted in $42 \%$ inactivation.

The method of LineweAver AND BuRK ${ }^{20}$ was used to estimate the values of $K_{\mathrm{m}}$ or $K_{\mathbf{i}}$ for the various substrates of the three enzymes. The measurements were made at different temperatures: with $E$. coli at $30^{\circ}, B$. megatherium at $40^{\circ}$ and $B$. subtilis at $50^{\circ}$. According to WALLENFELS and co-workers ${ }^{21}$ there is not much influence of the temperature on the Michaelis constant for ONPG for the $E$. coli enzyme. Consequently it is possible to compare at least the values for $K_{\mathrm{m}}$ or $K_{\mathrm{i}}$ for the enzymes of $E$. coli and $B$. subtilis. These values show considerable differences (Table II).

\section{ACKNOWLEDGEMENTS}

The author is much indebted to Professor Dr. P. G. De HaAn and Dr. A. H. StoutHAMER for stimulating discussions and helpful suggestions. He is grateful to Professor Dr. V. J. Koningsberger for his interest in this work. Thanks are due to Miss J. M. Coops for skilful assistance in several phases of the work.

\section{REFERENCES}

1 J. LEDERBERG, J. Bacteriol., 60 (I950) 38 I.

2M. Cohn AND J. Monod, Biochim. Biophys. Acta, 7 (1950) I 53.

s. A. Kuby and H. A. Lardy, J. Am. Chem. Soc., 75 (1953) 890.

4 A. S. L. Hu, R. G. Wolfe and F. J. Reithel, Arch. Biochem. Biophys., 81 (1959) 500.

5 K. Wallenfels, M. L. Zarnitz, G. Laule, H. Bender And M. Keser, Biochem. Z., 33 I (1959) 459 .

- A. B. Pardee, F. Jacob and J. Monod, J. Mol. Biol., i (1959) 165.

7 M. Riley, A. B. Pardee, F. Jacob and J. Monod, J. Mol. Biol., 2 (1960) 2 I6.

B F. Jacob and J. Monod, J. Mol. Biol., 3 (r96I) 318.

- H. R. Revel, S. E. Luria and B. Rotman, Proc. Natl. Acad. Sci. U.S., 47 (I961) 1956.

10 H. R. Revel and S. E. Luria, Proc. Natl. Acad. Sci. U.S., 47 (I96I) 1968.

11 H. R. Rhvel, S. E. Luria and N. L. Young, Proc. Natl. Acad. Sci. U.S., 47 (I96I) I974.

12 O. E. Landman, Biochim. Biophys. Acta, 23 (1957) 558.

18 C. R. Clausen AND M. NAKamURA, Nature, 197 (1963) 570.

14 J. Spizizen, Federation Proc., 18 (1958) 957.

15 J. Spizizen, Proc. Natl. Acad. Sci. U.S., 44 (1959) 1072.

16 C. B. Thorne, J. Bacteriol., 83 (I962) Io6.

17 G. Cohen-Bazire and M. Jolit, Ann. Inst. Pasteur, 84 (1953) 937.

18 O. Warburg and W. Christian, Biochem. Z., 3io (194I) 384 .

10 M. Merkenschiager, K. Schlossmann and W. KURz, Biochem. $Z$., 329 (1957) 332.

${ }^{20}$ H. Lineweaver and D. Burk, $J$. Am. Chem. Soc., 56 (r934) 658.

21 K. Wallenfels, J. Lehman and O. P. Malhotra, Biochem. Z., 333 (1960) 209.

$22 \mathrm{~J}$. JaneČEK AND H. V. RickenBerg, Biochim. Biophys. Acta, 81 (1964) 108. 